\title{
Bilateral Pneumothorax During Subdural-Peritoneal Shunting
}

\author{
Subdural-Peritoneal Şant Takılması Strasında Gelişen Bilateral \\ Pnömotoraks
}

Ilker SOLMAZ, Ozkan TEHLI, Serdar KAYA, Ersin ERDOGAN, Yusuf IZCI

Gulhane Military Medical Academy, Department of Neurosurgery, Ankara, Turkey

Correspondence address: Yusuf IZCI / E-mail: yusufizci@yahoo.com

\begin{abstract}
Pneumothorax is a very rare complication of ventriculoperitoneal shunting in children. We report a case of an iatrogenic bilateral tension pneumothorax during the placement of a subdural-peritoneal shunting. After the placement of peritoneal catheter, oxygen saturation of the patient quickly decreased, hypotension and bradycardia occurred. Intraoperative x-rays showed the pneumothorax. A thoracostomy tube was inserted and attached to an underwater seal. Vital signs improved in a short time period. The radiological improvement had been achieved in four days. Early diagnosis and prompt intervention are life-saving for this complication. To avoid this complication, the tip of the shunt tunneler should be always palpable during the placement of the peritoneal catheter, especially in children's shunt surgery.
\end{abstract}

KEYWORDS: Pneumothorax, Subdural-peritoneal shunt, Complication

öz

Pnömotoraks çocuklarda ventriküloperitoneal şantın çok nadir bir komplikasyonudur. Biz subdural-peritoneal şant takılması sırasında meydana gelen bilateral basınçlı pnömotoraks olgusunu rapor ettik. Ameliyat sırasında, peritoneal kataterin takılmasından hemen sonra hastada oksijen satürasyonu hızla düştü, hipotansiyon ve bradikardi gelişti. Çekilen intraoperatif röntgen hastada bilateral pnömotoraks geliştiğini gösterdi. Hemen hastaya torakostomi tübü yerleştirildi ve bu tüp sualtı drenajına bağlandı. Vital bulgular hızla düzeldi. Hastada radyolojik düzelme 4. günde meydana geldi. Erken tanı ve çabuk girişim bu komplikasyonda hayat kurtarıcı rol oynar. Bu nadir komplikasyonun önlenebilmesi için şant cerrahisinde peritoneal katater yerleştirilmesi sırasında, özellikle çocuklarda, tünel açıcının ucu her zaman palpabl (ele gelebilir) olmalıdır.

ANAHTAR SÖZCÜKLER: Pnömotoraks, Subdural-peritoneal şant, Komplikasyon

\section{INTRODUCTION}

Pneumothorax is the entrapment of air into the pleural space by lung rupture. In this condition, air accumulates between the lung and pleura and the intrapleural pressure increases progressively. Venous return is ultimately compromised, producing hypotension and shock. Although many causes exist for iatrogenic pneumothorax, mechanical ventilation is the most important one (3). Bilateral intraoperative pneumothorax is an extremely rare complication of shunt operations which may occur secondary to a valsalva maneuver or pleural tearing during the tunneling for peritoneal catheter. This complication resolves either spontaneously or can be treated by thoracostomy tube.

\section{CASE REPORT}

A 4-month-old female child was referred with the history of seizure and nausea/vomiting which began 2 weeks ago. Cranial computed tomography (CT) revealed biparietal subdural collections without compression on the cerebral tissue. Subdural tapping was performed and slightly xanthochromic fluid was dripped spontaneously. This procedure was repeated for several times to evacuate the collection, but CT scans showed re-collection. We decided to place a subdural-peritoneal shunt for the drainage of collection. Two parietal burr holes were opened and two cranial subdural catheters were inserted. Then, subcutaneous tunneling was performed for the peritoneal catheter and the peritoneal trocar was inserted as the anestesiologist induced a valsalva maneuver to tighten the abdominal muscles. The limit of positive end-expiratory pressure (PEEP) value was $5 \mathrm{~cm} \mathrm{H} 2 \mathrm{O}$. However, during the valsalva maneuver this PEEP value was probably higher than the limit for a short time. A few minutes after the placement of peritoneal catheter, oxygen saturation of the patient decreased quickly and hypotension and bradycardia occurred. An emergent chest x-ray showed bilateral pneumothorax (Figure 1). No underlying emphysematous change or bullous disease was identified. A thoracostomy tube was inserted and attached to an underwater seal. Radiological improvement was 


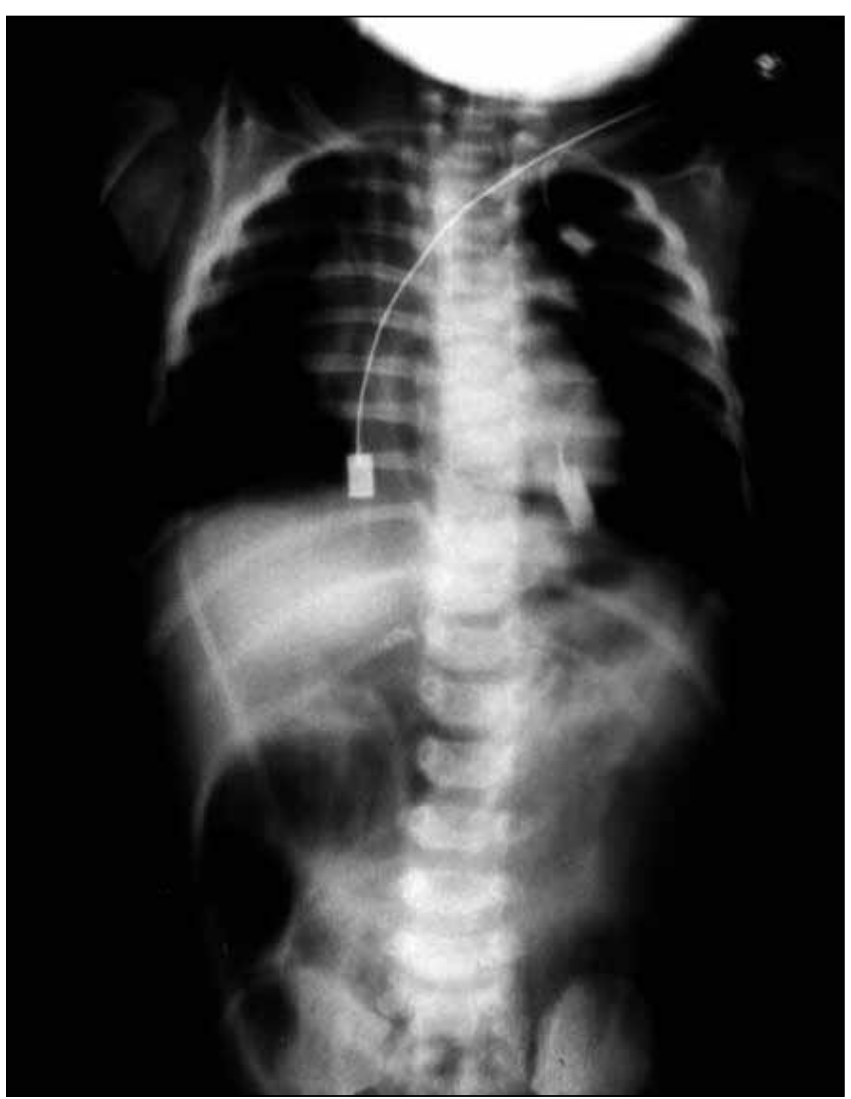

Figure 1: The intraoperative chest $x$-ray of the patient showing bilateral pneumothorax.

achieved in four days, and the patient discharged without complication. A chest CT was obtained after the surgery to rule out any other pathologies. The follow-up cranial CT scans showed the absence of subdural collection and control chest $\mathrm{x}$-rays were normal.

\section{DISCUSSION}

We report a case of bilateral tension pneumothorax which is a very rare complication of shunt operations. Alveolar overdistension during the valsalva maneuver is the possible cause of pneumothorax in this patient. Prompt intervention saved the life of the patient.

Bilateral spontaneous pneumothorax is a rare clinical event. Common causes of this condition have been reported to include trauma, tumor, tuberculosis, anesthesia, and iatrogenic causes from central line placement or intubation. Other episodes have been described in the literature in association with menstruation (catamenial pneumothorax), sarcoidosis, pregnancy, and radiation (1). latrogenic pneumothorax develops as a result of direct puncture or laceration of visceral pleura, transbronchial lung disruption or direct alveolar overdistention (anesthesia, cardiopulmonary resuscitation or mechanical ventilation) (3,5). Portnoy et al. reported the first case of pneumothorax after the placement of ventriculoperitoneal shunt in 1973 (4). Menguy et al. reported a case of respiratory distress syndrome (RDS) following ventriculo-peritoneal shunt procedure in 1986 and they stated that the RDS was related to surgical pneumothorax (2). Spontaneously resolving was occurred in this case and two possible mechanisms have been proposed for this complication. One is the alveolar overdistention during the mechanical ventilation and the other is pleural tear during the subcutaneous tunneling $(2,6)$. In our case, the positive pulmonary pressure increased when the valsalva maneuver had been performed, and pneumothorax occurred due to increased PEEP causing alveolar overdistention. Pleural tearing has been ruled out on the basis of bilateral settlement. In unilateral pneumothorax, there is a disruption or tear in the pleural membrane which creates a "one-way valve" system. Air escapes from a lung and occupies the pleural space between the chest wall and a lung. In bilateral pneumothorax, alveolar rupture, secondary to trapping of a large volume of air during the valsalva maneuver could be responsible for a pulmonary air leak.

In conclusion, pneumothorax is a rare and severe complication of shunt procedures, which should be kept in mind during the operation by neuroanesthesiologists and neurosurgeons. Subcutaneous tunneling must be performed meticulously and peritoneal trocar must be inserted without causing high PEEP value.

\section{REFERENCES}

1. Lewis RL, Moore JM, Kline AL: Simultaneous bilateral spontaneus pneumothorax. A case report. Current Surgery 59(1):99-100, 2002

2. Menguy $E$, Mangez JF, Roux $P$, Alibert F, Winckler C: Pneumothorax after ventriculoperitoneal shunt procedure. Ann Fr Anesth Réanim 5(6):615-616, 1986

3. Pierson DJ: Disorders of the pleura, mediastinum and diaphragm. In: Wilson JD, Braunwald E, Isselbacher KJ, Petersdorf RG, Martin JB, Fauci AS, Root RK, eds. Harrison's Principles of Internal Medicine. 12th ed. New-York: McGrawHill, 1991: 1113

4. Portnoy HD, Croissant PD: Two unusual complications of a ventriculoperitoneal shunt. Case report. J Neurosurg 39(6):775-776, 1973

5. Schul DB, Wolf $S$, Lumenta $C B$ : latrogenic tension pneumothorax resulting in pneumocephalus after insertion of a ventriculoperitoneal shunt: An unusual complication. Acta Neurochir (Wien) 152(1):143-144, 2010

6. Trotoux J: Les épanchements gazeux dans le médiastin, la cavité pleurale et les tissues sous-coutanés en période opératoire. Encycl Méd Chir Urgences 24:176, 1975 